\title{
Presence of Non-Maternal Antibodies in Newborns of Mothers with Antibody Deficiencies
}

\author{
M. HAHN-ZORIC, B. CARLSSON, J. BJÖRKANDER, A. D. M. E. OSTERHAUS, L. MELLANDER, \\ AND L. A. HANSON \\ Departments of Clinical Immunology and Pediatrics and the Allergy and Asthma Research Center, Department \\ of Internal Medicine I, University of Göteborg, Göteborg, Sweden and Rijksinstituut voor Volksgezondheid en \\ Milieuhygiene, Bilthoven, Holland
}

\begin{abstract}
To explain the mechanism for induction and production of specific antibodies found in the newborn already at birth, without previous known exposure to the antigen, we chose a model that presumably excluded the possibility of specific antibodies being transferred from the mother to the fetus. Specific IgG, IgA, and IgM antibodies against Escherichia coli and poliovirus antigens were determined with ELISA in serum, saliva, and amniotic fluid from hypogammaglobulinemic and IgA-deficient mothers as well as in cord serum, saliva, and meconium from their offspring. All the mothers lacked IgA and some also lacked IgM antibodies, which were found in their healthy newborns. The amniotic fluid from a hypogammaglobulinemic mother lacking IgA contained small amounts of $\operatorname{IgA}$ antibodies, which were also found in the neonate, suggesting a fetal origin. There was evidence for the presence of antiidiotypic antibodies to poliovirus in the cord sera. We propose that idiotypic and/or antiidiotypic IgG antibodies transferred via the placenta from the mother to the fetus can initiate specific immune responses seen in the newborn. Thus, it may be that transplacental IgG not only passively protects the newborn, but also actively primes the fetus during fetal life via its content of idiotypic and/or antiidiotypic antibodies. (Pediatr Res 32: 150-154, 1992)
\end{abstract}

\section{Abbreviations}

NMS, normal mouse serum

PBS-T, phosphate buffered saline with Tween

RF, rheumatoid factor

SC, secretory component

In an earlier study, we found specific secretory IgA and IgM antibodies to a pool of Escherichia coli $\mathrm{O}$ antigens and poliovirus type 1 antigen in amniotic fluid, saliva, and meconium of newborns already at birth (1). It was unlikely that these antibodies were of maternal origin, inasmuch as IgA and IgM are not known to pass the placenta. Furthermore, an infant of a hypogammaglobulinemic mother without detectable $\operatorname{IgA}$ and $\operatorname{IgM}$ antibodies had specific IgA and IgM antibodies in saliva against $E$. coli $\mathrm{O}$ antigen as well as poliovirus type 1 antigen already at birth (1). The presence of antibodies to poliovirus in Swedish newborns was especially difficult to explain, inasmuch as wild or vaccine strains of poliovirus do not circulate in the community because

Received November 28, 1991; accepted March 10, 1992.

Correspondence: Mirjana Hahn-Zoric, Department of Clinical Immunology, Guldhedsgatan 10, S-413 46 Göteborg, Sweden.

Supported by grants from the Swedish Medical Research Council (no. 215), the Ellen, Lennart and Walter Hesselman Foundation, and KabiPharmacia, Stockholm, Sweden. close to $99 \%$ of the population has been efficiently vaccinated using inactivated poliovirus vaccine exclusively. Therefore, the fetuses were unlikely to have been exposed to poliovirus antigen in utero, suggesting that the secretory $\operatorname{IgA}$ and $\operatorname{IgM}$ antibodies had been produced by the fetus in response to another stimulus, e.g. idiotypic and/or antiidiotypic antibodies to poliovirus. Such antibodies were demonstrated in the Ig preparation given prophylactically to the mothers with hypogammaglobulinemia (Hahn-Zoric M, Carlsson B, Jeansson S, Ekre HP, Osterhaus ADME, Roberton D, Hanson LA, unpublished data).

In the present study, we have tested a group of hypogammaglobulinemic or IgA-deficient mothers and their newborns to further analyze antibodies appearing in the neonate that presumably could not have come from the mother.

\section{MATERIALS AND METHODS}

Samples from four hypogammaglobulinemic mothers and their newborns as well as two IgA-deficient mothers and their neonates were studied. Mother I whose first infant was investigated earlier (1), now had her second baby investigated. From mother II samples from two pregnancies were included. At delivery, we tried to obtain amniotic fluid, cord serum, and mother's serum. Cord blood was taken from the placental side of the umbilical cord. All samples were frozen at $-20^{\circ} \mathrm{C}$. During the first few days postpartum, mother's and infant's saliva, meconium, and maternal milk (not included in this study) were collected. Samples were frozen immediately at $-20^{\circ} \mathrm{C}$. The babies had not been given either the mother's or bank milk before the sample was taken. The time passed from the last feeding was recorded, as was the mode of feeding. The saliva was obtained as unstimulated whole saliva with a $1-\mathrm{mL}$ syringe or a rounded eye-drop pipette during $15 \mathrm{~min}$ and was immediately frozen at $-20^{\circ} \mathrm{C}$.

The hypogammaglobulinemic mothers were on prophylaxis with $16.5 \%$ Ig intramuscularly (Gammaglobulin; KabiPharmacia, Stockholm, Sweden), a preparation shown to contain idiotypic and antiidiotypic antibodies to poliovirus type 1 (HahnZoric M, Carlsson B, Jeansson S, Ekre HP, Osterhaus ADME, Roberton D, Hanson LA, unpublished data).

Preparation of meconium extracts. Previously freeze-dried meconium samples were weighed, and $0.1 \mathrm{~g}$ of dry material was dissolved in $3 \mathrm{~mL}$ of $\mathrm{PBS}, \mathrm{pH} 7.2$, in centrifuge tubes with round bottoms. Glass beads were added to each test tube and the mixture was shaken on a whirl-mixer six times during a 30 -min interval with a 5 -min pause in between at $4^{\circ} \mathrm{C}$. After that, the samples were centrifuged for $20 \mathrm{~min}$ at $1500 \times \mathrm{g}$ and the clear supernatant was used immediately for analysis. Tween 20 (Merck, Darmstadt, Germany) was added in a concentration of $0.05 \%$ to the extracts that were analyzed undiluted.

Antibody determinations. Total maternal serum IgG, IgM, and IgA levels were quantified by radial immunodiffusion (2). IgA 
deficiency was diagnosed as serum $\operatorname{IgA}$ levels $\leq 0.05 \mathrm{~g} / \mathrm{L}$ and normal levels of other Ig. Hypogammaglobulinemia was defined by significantly decreased serum IgG levels $(<2-3 \mathrm{~g} / \mathrm{L})$ and decreased or undetectable serum IgA and often also IgM levels. IgA was absent in serum of all six mothers (Table 1).

Antigen-specific Ig were analyzed in a modified ELISA $(3,4)$, using hard, polystyrene microtiter plates with flat bottoms (Dynatech, Alexandria, VA or NUNC Immunoplate I, Roskilde, Denmark). The sensitivity of this method allows detection of $<$ $1 \mathrm{ng} / \mathrm{mL}$ of specific antibody. The plates were coated either with a pool of 10 common $E$. coli $\mathrm{O}$ antigens or with a concentrated inactivated poliovirus type 1 vaccine to $95 \%$ composed of $\mathrm{D}$ antigen and produced at the Rijksinstituut voor Volksgezondheid en Milieuhygiene, Bilthoven, the Netherlands. Rabbit antisera against human $\operatorname{IgA}(\alpha$-chain specific), IgM ( $\mu$-chain specific), and IgG ( $\gamma$-chain specific) (Dakopatts, Copenhagen, Denmark), as well as sheep anti-human SC (Seward Lab, London, UK), were conjugated to alkaline phosphatase (Boehringer Mannheim, Mannheim, Germany) and used for determination of antibodies in amniotic fluid, saliva, cord blood, and serum. The reaction between alkaline phosphatase and enzyme substrate $(1 \mathrm{mg} / \mathrm{mL}$ of $p$-nitro-phenyl-phosphate disodium; Sigma Chemical Co., St. Louis, MO) in $1 \mathrm{M}$ diethanolamine buffer, $\mathrm{pH} 9.8$, containing $0.001 \mathrm{M} \mathrm{MgCl} 2$ was read in a Titertek Multiscan (Flow Labs, Ayrshire, Scotland) at $405 \mathrm{~nm}$ after appropriate reaction time, whereas the enzyme-substrate reaction was linear and then usually extrapolated to $100 \mathrm{~min}$. Because of the presence of high concentrations of alkaline phosphatase in meconium, a double antibody ELISA was used instead for this material, using rabbit antisera against human IgA, IgM, or SC (Dakopatts) as primary antibody. As second antibody, goat anti-rabbit $\gamma$-chain-specific rabbit IgG conjugated to $\beta$-galactosidase (Southern Biotechnology Associates Inc., Birmingham, AL) was added. O-nitrophenyl$\beta$-D-galactopyranoside (Sigma) in a concentration of $1.4 \mathrm{mg} / \mathrm{mL}$ in $0.2 \mathrm{M}$ phosphate buffer, $\mathrm{pH} 7.0$, containing $2.0 \mathrm{mM} \mathrm{MgCl} 2$ was used as enzyme substrate. The plates were read at $405 \mathrm{~nm}$ as above. All the samples were run in four 10-fold dilutions, starting from undiluted for meconium and amniotic fluid, 1:5 for saliva and 1:100 for serum and cord serum.

The antibody levels were expressed as a percentage of a reference that was a human early milk pool diluted 1:10 for IgA, IgM, and SC in secretions and amniotic fluid and a serum standard diluted 1:100 for IgG as well as for serum and cord blood IgA and IgM. The serum standard used was a high-titered single patient's serum collected by plasmaphoresis and defibrinized. It was previously tested against a commercial serum pool and has been used in our laboratory during the last two decades.

The standards were used in each assay to ensure the inter- and intraassay reproducibility of the method, which was $<10 \%$ and $<5 \%$, respectively.

Determination of antiidiotypic antibodies. Cord blood samples from the newborns of three hypogammaglobulinemic and one IgA-deficient mother were tested in two specially designed and previously used ELISA for the detection of antiidiotypic antibodies against poliovirus type 1 (5). NUNC plates were coated with mouse monoclonal IgG antibodies to poliovirus type 1, desig-

Table 1. Concentration of serum $I^{*}(g / L)$ in immunodeficient mothers

\begin{tabular}{cccc}
\hline Mother & IgG & IgA & IgM \\
\hline I & $0.0 \dagger$ & 0.0 & 0.0 \\
II & $4.6 / 5.1 \ddagger$ & $0.0 / 0.0 \ddagger$ & $0.7 / 0.2 \ddagger$ \\
III & 6.1 & $<0.01$ & $<0.1$ \\
IV & 2.3 & 0.0 & 0.5 \\
V & 20.7 & 0.0 & 1.9 \\
VI & 15.0 & 0.0 & 3.7 \\
\hline
\end{tabular}

* Determination of serum Ig levels closest to partus.

$\dagger$ Serum Ig levels before treatment with Ig preparation.

$\ddagger$ Partus no. 2 . nated 3-4E4 (IgG1), 2-20FW (IgG1), and 5D9D6 (IgG2b) or a bovine polyclonal IgG anti-poliovirus type 1 antibody, D-antigen specific. After incubation overnight at $37^{\circ} \mathrm{C}$, blocking was done with $1 \%$ fish gelatin (Sigma) in PBS for $1 \mathrm{~h}$ at room temperature. In the direct binding assay, cord serum samples were added to the plates in 10-fold dilution series in $1 \%$ gelatin-PBS-T and $10 \%$ NMS (Calbiochem, Behring Diagnostics, La Jolla, CA). After 4 $\mathrm{h}$ incubation at room temperature, alkaline phosphatase-conjugated $(\mathrm{Fab})_{2}$ mouse anti-human IgG (Jackson Immuno Research Laboratories Inc., West Grove, PA) diluted 1:5000 in 1\% gelatinPBS-T was added, and after incubation overnight at room temperature the enzyme substrate was added and the plates were read as described above. Sample-free and antibody-free controls were included to check any unspecific binding.

The competitive inhibition assay used is based on the ability of antiidiotypic antibodies to inhibit the binding of antigen to the homologous antibody. The cord sera were added to the plates coated with antibodies to poliovirus in a dilution of 1:200 in $10 \%$ NMS- $1 \%$ gelatin-PBS-T as above. After incubation for $4 \mathrm{~h}$ at room temperature, poliovirus type 1 antigen was added in appropriate dilutions in $1 \%$ gelatin-PBS-T. After incubation overnight at $4^{\circ} \mathrm{C}$, the polyclonal rabbit anti-poliovirus type 1 antibody diluted $1: 1000$ in $10 \%$ NMS $1 \%$ gelatin-PBS-T was incubated in the plates for $4 \mathrm{~h}$ at room temperature. Alkaline phosphatase-conjugated goat anti-rabbit IgG $(\mathrm{Fab})_{2}$ fraction (Sigma) diluted $1: 1000$ in $10 \%$ NMS-1\% gelatin-PBS-T was added to the plates, and after $3 \mathrm{~h}$ incubation at $37^{\circ} \mathrm{C}$ the substrate was added and the plates were read as indicated above. Samplefree, antigen-free, sample and antigen-free, and MAb-free controls were used to exclude any nonspecific binding between the different reagents.

Detection of $R F$. Cord sera from the infants of three hypogammaglobulinemic and one IgA-deficient mother were negative in a class-specific diffusion-in-gel ELISA for determination of RF (6). In a more sensitive direct ELISA described above, there is a possibility that RF, if present, may give false-positive results when determining the antiidiotypic antibodies against poliovirus type 1. The nonspecific binding of the RF to the Fc portion of either coated mouse MAb or human antiidiotypic antibody would enhance the detection by the conjugated antibody.

An optimal dilution of each sample was mixed with different dilutions of isolated $\mathrm{Fc}$ fragments of $\mathrm{IgG}$ (kindly given by $\mathrm{Dr}$. B. G. Johansson, Dakopatts) for $1 \mathrm{~h}$ at $37^{\circ} \mathrm{C}$ before being added to the plates coated with two MAb (5D9D6 and 7D7D8) and the polyclonal anti-polio antibody. Thus, the free Fc would bind to any RF present, blocking their binding to the unwanted sites, preventing interference with the assay. An RF-negative and a strongly RF-positive serum were used as controls as well as an Fc-free control for each sample.

Specificity controls. Control experiments ensuring the specificity of antigen-antibody binding, as well as inhibition experiments proving the specificity of antigens used, were performed (7).

\section{RESULTS}

Antibodies in hypogammaglobulinemic mothers and their newborns. All three mothers with available sample had $\mathrm{IgG}$ antibodies against both the $E$. coli and poliovirus antigens in the amniotic fluid, and in the sample from the first pregnancy of mother II there were low levels of IgM antibodies as well. Amniotic fluid from her second pregnancy contained very low levels of IgA antibodies against poliovirus type 1 antigen; such antibodies were not detectable in the mother's serum (Table 2).

In the sera of all the mothers, we found high levels of IgG antibodies against poliovirus type 1 antigen and about half of the reference value against $E$. coli $\mathrm{O}$ antigens (Table 2). Mothers I, III, and IV had no IgA or IgM in their sera, whereas mother II had no IgA and very low levels of IgM. Newborns of mothers I, II, and III had only IgG antibodies in their cord sera, but the 
Table 2. Serum and secretory antibodies to poliovirus type 1 antigen and E. coli $O$ antigens in mothers with hypogammaglobulinemia and their newborns, as determined with ELISA and expressed as \% of references.

\begin{tabular}{|c|c|c|c|c|c|c|c|c|}
\hline & \multicolumn{4}{|c|}{ Poliovirus type 1} & \multicolumn{4}{|c|}{ E. coli $\mathrm{O}$ antigen pool } \\
\hline & $\operatorname{Ig} \mathrm{A}$ & IgG & IgM & $\mathrm{SC}^{*}$ & IgA & $\operatorname{IgG}$ & IgM & SC \\
\hline Mother I serum & 0 & 92.2 & 0 & $\mathrm{NT} \dagger$ & 0 & 47.6 & 0 & NT \\
\hline Newborn serum & 0 & 89 & 0 & NT & 0 & 43.8 & 0 & NT \\
\hline Mother I saliva & 0 & 3.6 & 0 & 0 & 0 & 5.8 & 0 & 0 \\
\hline $\begin{array}{l}\text { Newborn } \\
\text { Saliva }\end{array}$ & $18.3 \pm$ & 3.6 & 29.1 & 576 & 83 & \multicolumn{3}{|c|}{ Newborn } \\
\hline Meconium & $\mathrm{ND \S}$ & ND & $\mathrm{ND}$ & $\mathrm{ND}$ & $\overline{\mathrm{ND}}$ & ND & $\frac{21.9}{\mathrm{ND}}$ & $\frac{14.6}{\mathrm{ND}}$ \\
\hline Amnion & 0 & 29.8 & 0 & 0 & 0 & 37.9 & 0 & 0 \\
\hline Mother II serum & 0 & 94.8 & 3.8 & NT & 0 & 34.9 & 5.5 & NT \\
\hline Newborn serum & 0 & 97.8 & 0 & NT & 0 & 48.2 & 0 & NT \\
\hline Mother II saliva & 0 & 6 & 0 & 0 & 0 & 22 & 0 & 0 \\
\hline \multicolumn{9}{|l|}{ Newborns $1 / 2 \|$} \\
\hline Saliva & $0 / 1 \|$ & ND & 49.7 & Tracef & $0 / 1.2 \|$ & ND & 0 & 0 \\
\hline Meconium & $0^{-1}$ & NT & $\overline{0}$ & $\overline{0}$ & 1 & NT & 0 & 0 \\
\hline Amnion & $0 / \underline{1.5} \|$ & 57.1 & 12.1 & 0 & $\overline{0}$ & 70.8 & 3.5 & 0 \\
\hline Mother III serum & 0 & 109.8 & 0 & NT & 0 & 20.7 & 0 & NT \\
\hline Newborn serum & 0 & 60.3 & 0 & NT & 0 & 19.6 & 0 & NT \\
\hline Mother III saliva & 0 & 1.7 & 0 & 14.7 & 0 & Trace & 0 & 4.6 \\
\hline \multicolumn{9}{|l|}{ Newborn } \\
\hline Saliva & $\underline{6.5}$ & 0 & 0 & 10.8 & $\underline{4}$ & 1.3 & 0 & 7.4 \\
\hline Meconium & $\overline{1.7}$ & NT & 1.6 & 10.8 & $\overline{4} .3$ & NT & 3.4 & 12 \\
\hline Amnion & 0 & 95.9 & $\overline{0}$ & 2.1 & $\overline{0}$ & 21.3 & 0 & 0 \\
\hline Mother IV serum & 0 & 99.8 & Trace & NT & 0 & 22.1 & 0 & NT \\
\hline Newborn serum & 0 & 93.5 & 0 & NT & 0 & 100.5 & $\underline{12.9}$ & NT \\
\hline Mother IV saliva & 0 & Trace & Trace & 0 & 0 & 2 & $\overline{0}$ & 0 \\
\hline \multicolumn{9}{|l|}{ Newborn } \\
\hline Saliva & 9.1 & ND & 11.2 & 14 & 15.8 & ND & 38.2 & 21.8 \\
\hline Meconium & 0 & NT & 0 & Trace & Trace & NT & 0 & 0 \\
\hline
\end{tabular}

* SC, secretory component-containing antibodies.

$\dagger$ NT, not tested.

$\ddagger$ Underlining signifies antibodies found in the newborn but not in the mother.

$\S N D$, not done due to insufficient volumes or unavailable sample.

\|I Antibodies found in the second child of mother II that were not found in the mother.

I Trace $=<1 \%$.

newborn of mother IV had serum IgM antibodies against $E$. coli $\mathrm{O}$ antigens.

Salivary antibodies in all four mothers were negative for $\operatorname{IgA}$ and IgM antibodies. Mothers I, II, and IV had no SC-carrying antibodies either, but mother III had such antibodies in her saliva. IgG antibodies were found in the saliva of all three mothers.

All four newborns had $\operatorname{IgA}, \operatorname{IgM}$, and SC-carrying antibodies against both antigens in their secretions, e.g. saliva and/or meconium (Table 2). The neonates had such antibodies although they were missing in their mothers (underlined values in Table 2).

Antibodies in IgA-deficient mothers and their newborns. Amniotic fluid was available only from mother VI. Besides IgG, it also contained high levels of IgM antibodies and low levels of IgA and SC-containing antibodies (Table 3).

Both mothers had serum IgG that was high against poliovirus and lower against $E$. coli $\mathrm{O}$ antigens with varying levels of IgM antibodies (Table 3 ). In the one cord serum available (from newborn $\mathrm{V}$ ), there were $\mathrm{IgG}$ antibodies against both antigens at higher levels than in the mother's serum and also low levels of serum IgA and IgM against poliovirus type 1 (Table 3 ).

The saliva was available only from mother V. IgA antibodies were undetectable in her saliva, but both she and her newborn had elevated salivary IgM antibodies. Both newborns, however, had IgA antibodies in saliva against both antigens. Also, they both had SC-containing antibodies and the newborn of mother $\mathrm{V}$ had IgG and IgM as well, whereas the saliva of the newborn of mother VI contained no IgG and no IgM against poliovirus on the first day after delivery.

There were IgM and/or IgA antibodies in meconium from the newborns sampled on a few different occasions. Neonate VI had IgA antibodies against poliovirus type 1 up to $5 \%$ of the reference and a trace of IgM antibodies against both antigens in meconium. IgM antibodies against poliovirus type 1 were found in meconium of infant $\mathrm{V}$. Traces of IgA antibodies were also found in the infant of mother $\mathrm{V}$, although such antibodies were not present in the mother (Table 3).

Antiidiotypic antibodies in cord sera. All four cord sera analyzed showed in the direct assay binding of antibodies to the murine MAb against poliovirus type 1 antigen as well as to the bovine polyclonal IgG against poliovirus type 1 antigen (Table 4). There were indications that some cord sera bound better than others to the different idiotypes against poliovirus. We found no evidence that RF interfered with this direct assay. Fc-free samples and mixtures of samples with different concentrations of Fc gave the same readings as did the RF-negative and RF-positive serum.

In the competitive assay, all the cord sera could inhibit the binding of poliovirus type 1 antigen to at least one of the MAb and to the polyclonal antibody against poliovirus type 1 antigen. The level of inhibition varied again among the four individuals and the different idiotypes (Table 5).

\section{DISCUSSION}

In the present study, we have demonstrated that newborn infants of hypogammaglobulinemic or IgA-deficient mothers can 
Table 3. Serum and secretory antibodies to poliovirus type 1 antigen and E. coli $O$ antigens in mothers with IgA deficiency and their newborns, as determined with ELISA and expressed as \% of references

\begin{tabular}{|c|c|c|c|c|c|c|c|c|}
\hline & \multicolumn{4}{|c|}{ Poliovirus type 1} & \multicolumn{4}{|c|}{ E. coli $\mathrm{O}$ antigen pool } \\
\hline & $\operatorname{Ig} A$ & $\mathrm{IgG}$ & $\operatorname{IgM}$ & $\mathrm{SC}^{*}$ & IgA & $\mathrm{IgG}$ & IgM & $\mathrm{SC}$ \\
\hline Mother V serum & 0 & 95.2 & 60.2 & $\mathrm{NT} \dagger$ & 0 & 42.8 & 35.3 & NT \\
\hline Newborn serum & $\underline{7 \ddagger}$ & 194.0 & 1.4 & NT & 0 & 89.5 & 0 & NT \\
\hline $\begin{array}{l}\text { Mother V saliva } \\
\text { Newborn }\end{array}$ & 0 & 8.8 & 206.5 & 18.8 & 0 & 10 & 384.7 & 24.1 \\
\hline $\begin{array}{l}\text { Saliva } \\
\text { Meconium }\end{array}$ & $\frac{43}{0}$ & $\begin{array}{r}28 \\
\text { NT }\end{array}$ & $\begin{array}{r}1982 \\
1.8\end{array}$ & $\begin{array}{r}203 \\
0\end{array}$ & $\frac{9}{\text { Trace } \|}$ & $\begin{array}{l}\text { ND§ } \\
\text { NT }\end{array}$ & $\begin{array}{c}476.7 \\
0\end{array}$ & $\begin{array}{c}\text { ND } \\
0\end{array}$ \\
\hline $\begin{array}{l}\text { Mother VI serum } \\
\text { Newborn serum }\end{array}$ & $\begin{array}{c}0 \\
\text { ND }\end{array}$ & $\begin{array}{l}106 \\
\text { ND }\end{array}$ & $\begin{array}{l}86 \\
\text { ND }\end{array}$ & $\begin{array}{l}\text { NT } \\
\text { ND }\end{array}$ & $\begin{array}{l}\text { ND } \\
\text { ND }\end{array}$ & $\begin{array}{l}\text { ND } \\
\text { ND }\end{array}$ & $\begin{array}{l}\text { ND } \\
\text { ND }\end{array}$ & $\begin{array}{l}\text { ND } \\
\text { ND }\end{array}$ \\
\hline $\begin{array}{l}\text { Mother VI saliva } \\
\text { Newborn }\end{array}$ & ND & ND & ND & ND & ND & ND & ND & ND \\
\hline Saliva & 18.3 & 0 & 0 & 94 & 29.1 & 0 & 16.7 & 16 \\
\hline Meconium & $\overline{4.9}$ & NT & Trace & ND & Trace & NT & Trace & 0 \\
\hline Amnion & 6.1 & 26.7 & 100.3 & 22.2 & Trace & 52.5 & 11.5 & 8.7 \\
\hline
\end{tabular}

${ }^{*} \mathrm{SC}$, secretory component-containing antibodies.

$\dagger$ NT, not tested.

$\ddagger$ Underlining signifies antibodies found in the newborn but not in the mother.

$\S \mathrm{ND}$, not done due to insufficient volumes or unavailable sample.

$\|$ Trace $=<1 \%$

Table 4. Direct binding of antiidiotypic antibodies against poliovirus type 1 antigen in cord sera to solid phase-bound antibodies to poliovirus type 1

\begin{tabular}{|c|c|c|c|c|}
\hline \multirow{3}{*}{$\begin{array}{l}\text { Cord } \\
\text { serum }\end{array}$} & \multicolumn{4}{|c|}{$\begin{array}{l}\text { Absorbance at } 1: 10 \text { dilution of } \\
\text { cord sera and after } 20 \text { min reaction time* }\end{array}$} \\
\hline & \multicolumn{3}{|c|}{$\begin{array}{l}\text { Monoclonal anti-poliovirus } \\
\text { type } 1\end{array}$} & \multirow{2}{*}{$\begin{array}{c}\text { Polyclonal } \\
\text { anti-poliovirus } \\
\text { type } 1\end{array}$} \\
\hline & $3-4 \mathrm{E} 4$ & $2-20 \mathrm{FW}$ & 5D9D6 & \\
\hline I & 0.5 & 0.5 & 0.7 & 0.6 \\
\hline II & 0.7 & 0.7 & 1.0 & 0.4 \\
\hline IV & 0.7 & 1.5 & 0.3 & 0.8 \\
\hline V & 0.8 & 1.2 & 0.7 & $>2.0$ \\
\hline
\end{tabular}

* Mean of duplicate determinations.

Table 5. Competitive inhibition of binding of poliovirus type 1 antigen to solid phase-bound poliovirus type 1 antibodies by antiidiotypic antibodies in cord sera

\begin{tabular}{|c|c|c|c|c|}
\hline \multirow{3}{*}{$\begin{array}{l}\text { Cord } \\
\text { serum }\end{array}$} & \multicolumn{4}{|c|}{$\begin{array}{l}\text { Maximal inhibition in } \% \text { of } \\
\text { sample-free control* }\end{array}$} \\
\hline & \multicolumn{3}{|c|}{$\begin{array}{c}\text { Monoclonal anti-poliovirus } \\
\text { type } 1\end{array}$} & \multirow{2}{*}{$\begin{array}{c}\text { Polyclonal } \\
\text { anti-poliovirus } \\
\text { type } 1\end{array}$} \\
\hline & $3-4 \mathrm{E} 4$ & $2-20 \mathrm{FW}$ & 5D9D6 & \\
\hline I & 87 & 13 & 60 & 10 \\
\hline II & 41 & 41 & 42 & 61 \\
\hline IV & 0 & 0 & 43 & 61 \\
\hline $\mathrm{V}$ & 50 & 12 & 100 & 100 \\
\hline
\end{tabular}

* Mean of duplicate determinations.

have specific IgA and IgM antibodies in saliva and meconium against poliovirus and $E$. coli $\mathrm{O}$ antigens. In several instances, the infants had such antibodies although they were not found in their mothers. These fetuses were unlikely to have been exposed to poliovirus in utero. Exposure to $E$. coli $\mathrm{O}$ antigens cannot be excluded. We presume that these IgM and IgA antibodies have been produced by the fetuses themselves, because the samples were collected at delivery before any breast milk was given. When milk samples from the hypogammaglobulinemic mothers were analyzed, they contained exclusively $\operatorname{IgG}$ antibodies against the two antigens (8). Comparing these antibody levels to a breast milk reference pool, they exceeded the normal levels severalfold. The IgA-deficient mothers also had greatly increased levels of IgG antibodies in milk and sometimes extremely elevated levels of IgM as well (8). That might be a part of a compensating mechanism in these mothers.

The antibodies in amniotic fluid could be produced either by mother or fetus. In the amniotic fluid from one hypogammaglobulinemic mother who had low levels of $\lg M$ antibodies in her serum, low levels of IgM antibodies were found. Thus, the origin of that IgM was not clear. However, the very low levels of IgA antibodies found in the amniotic fluid of the second child of mother II speak in favor of fetal production, because the mother totally lacked such antibodies. Of the two IgA-deficient mothers, only one had available amniotic fluid, and the origin of the IgM antibodies found was not obvious because the mother compensated well with $\operatorname{IgM}$ antibodies. In this amniotic fluid, low levels of IgA and SC-containing antibodies were also demonstrated. Their origin was not certain either, inasmuch as this mother had no available salivary sample for analyzing, but it could possibly be of fetal origin because individuals lacking serum IgA almost in all instances are also lacking this Ig in their secretions.

The mothers with hypogammaglobulinemia and their infants had $\mathrm{IgG}$ antibodies to poliovirus type 1 antigen in their sera presumably originating from the Ig preparations given to these mothers and known to contain idiotypic and antiidiotypic antibodies to poliovirus (Hahn-Zoric M, Carlsson B, Jeansson S, Ekre HP, Osterhaus ADME, Roberton D, Hanson LA, unpublished data). The IgA-deficient mothers had normal IgG levels. $\mathrm{IgG}$ antibodies reached the fetuses as idiotypic and antiidiotypic antibodies, possibly providing the stimulus for the antibody production of the fetus.

Animal experiments have earlier demonstrated that idiotypes and antiidiotypes can prime newborn mice to respond more efficiently to immunization with protection against subsequent challenge with live bacteria (9). The priming effect was also demonstrated when mothers were immunized with antiidiotypes shortly after delivery. Their suckling offspring were protected from challenge with $E$. coli as well. Okamoto et al. (10) showed that neonatal mice can be protected by idiotypes transferred via the mother's milk, either by a priming effect to subsequent 
antigen challenge or by passively transferred protection. We have recently shown that breast-feeding seemed to enhance serum and secretory antibody responses to peroral poliovirus and parenteral tetanus and diphtheria toxoid vaccines in infants, possibly because of the presence of idiotypic and/or antiidiotypic antibodies in mother's milk. Even 2-3 y later, the serum antibody levels were higher in the breast-fed compared to the formula-fed infants (11). We have also found evidence for antiidiotypic antibodies against poliovirus type 1 in human milk (Hahn-Zoric M, Carlsson B, Jeansson S, Ekre HP, Osterhaus ADME, Roberton D, Hanson LA, unpublished data). A similar enhancement of the response to the Bacillus Calmette-Guérin and conjugate Haemophilus influenzae type b vaccines by breast-feeding was also reported $(12,13)$.

In intrauterine infections, the fetus is capable of an immune response against infecting microorganisms (14). Idiotypic sensitization in utero has also been demonstrated in children born to mothers with chronic parasitic infections. These children were born with $\mathrm{T}$ lymphocyte-mediated antiidiotype reactivity, a priming that might be important if they became infected (15). The fetus can produce specific antibodies against antigens to which the mother has been vaccinated during pregnancy as well $(16,17)$.

Transient synthesis of antibodies to the acetylcholine receptor has been demonstrated in newborns with neonatal myasthenia gravis, born to myasthenic mothers (18). The receptor antibodies found at birth in the symptomatic infants were often of different idiotypes than those found in their mothers. El-Roeiy et al. (19) have shown that infants of mothers with systemic lupus erythematosus had autoantibodies that were absent in the mothers. This indicated fetal autoantibody production.

It was recently shown in an animal model that oral immunization with xenogeneic antibodies results in both systemic and mucosal anti-Ig responses (20). Female rabbits were fed with murine IgA antibody and their serum and colostrum samples contained antiidiotypic antibodies against the murine antibody, some of which were antibodies directed against the antigenbinding site. This was determined by a competitive inhibition assay. Another indication that an immune response in different species elicits the formation of antibodies that express a common idiotype was provided by an observation that a murine MAb specific for ryegrass pollen allergen Lol p IV, could inhibit the binding of a mouse, human, and rabbit antisera to Lol p IV (21). Furthermore, the same antisera to Lol p IV could inhibit the idiotype-antiidiotype interactions. Thus, the monoclonal antiidiotypic antibody was characterized as an internal image antiidiotype.

It was found in adult mice that immunization with the antiidiotypic antibodies to poliovirus could successfully induce neutralizing poliovirus antibodies (22). In the present study, we have demonstrated direct binding and inhibition of poliovirus antigenbinding to antibodies against poliovirus with cord sera from infants of mothers with IgA deficiency or hypogammaglobulinemia. We propose that this reactivity is due to the presence of antiidiotypic antibodies to poliovirus antigens in these cord sera. Because the balance between the idiotypic and antiidiotypic antibodies may play an important role in the regulation of the normal immune response, their presence in the fetus may also have an impact on the fetal immune response. Idiotypes and/or antiidiotypes, transferred from the mother may prime the fetus and enhance its own capacity to produce protective antibodies. On the other hand, it may be possible that sensitization to common allergens, e.g. food allergens, may occur via the same mechanism.
Acknowledgments. The authors thank Eeva Nisshagen, Ingela Delgado, and Ann-Marie Månquist for expert technical assistance.

\section{REFERENCES}

1. Mellander L, Carlsson B, Hanson LA 1986 Secretory IgA and IgM antibodies to $E$. coli $\mathrm{O}$ and poliovirus type 1 antigens occur in amniotic fluid, meconium and saliva of newborns. A neonatal immune response without antigenic exposure: a result of anti-idiotypic induction? Clin Exp Immunol 63:555561

2. Mancini G, Carbonara AO, Heremans JF 1965 Immunochemical quantitation of antigens by single radial immunodiffusion. Immunochemistry 2:235-254

3. Ahlstedt S, Carlsson B, Hanson LÄ, Kaijser B, Mattsby Baltzer I, Sohl Akerlund $\AA 1978$ Application of the ELISA for determination of immunoglobulin class-specific $E$. coli antibodies. Scand J Immunol 8(suppl 7):119-124

4. Carlsson B, Zaman S, Jalil F, Mellander L, Hanson LA 1985 Secretory and serum immunoglobulin class-specific antibodies to poliovirus after vaccination. J Infect Dis 152:1238-1244

5. Hanson LA, Carlsson B, Hahn-Zoric M, Osterhaus ADME, Roberton D 1989 Immunoregulation mother-fetus/newborn, a role for anti-idiotypic antibodies? Acta Paediatr Scand [Suppl] 351:38-41

6. Tarkowski A, Bjursten LM, Nilsson LÄ, Nygren H 1983 False positive results in class-specific rheumatoid factor (RF) assays due to interaction between $\mathrm{RF}$ and $\mathrm{Fc}$ fragments of anti-immunoglobulin indicator reagents. J Immunol Methods 58:171-182

7. Hahn-Zoric M 1991 Secretory Antibodies, Their Induction and Characteristics in the Neonate and Adult. Thesis, University of Göteborg, Göteborg, Sweden.

8. Hanson LÄ, Söderström R. Friman V, Hahn-Zoric M, Czerkinsky C, Quiding M, Cardinale F, Beres Castrignano S, Theman K, Björkander J, Kilander A, Söderström T, Carlsson B, Mellander L, Carneiro-Sampaio M, Holmgren J 1991 Update on IgA and IgG subclass deficiency. In: Chapel HM, Levinsky RJ, Webster ADB (eds) Progress in Immune Deficiency III. Royal Soc Med Serv Ltd, London, pp 1-6

9. Stein KE, Söderström T 1984 Neonatal administration of idiotype or antiidiotype primes for protection against Escherichia coli $\mathrm{K} 13$ infection in mice. J Exp Med 160:41-48

10. Okamoto Y, Tsutsumi H, Kumar NS, Ogra PL 1989 Effect of breastfeeding on the development of anti-idiotype response to $F$ glycoprotein of respiratory syncytial virus in infant mice after post-partum maternal immunization. $J$ Immunol 142:2507-2512

11. Hahn-Zoric M, Fulconis F, Minoli J, Moro G, Carlsson B, Böttiger M, Räihä N 1990 Antibody responses to parenteral and oral vaccines are impaired by conventional and low protein formulas as compared to breastfeeding. Acta Paediatr Scand 79:1137-1142

12. Pabst HF, Godel J, Grace M, Cho H, Spady DW 1989 Effect of breast-feeding on immune response to BCG vaccination. Lancet 1:295-297

13. Pabst HF, Spady DW 1990 Effect of breast-feeding on antibody response to conjugate vaccine. Lancet 336:269-270

14. Stagno S, Volanakis J, Reynolds DW, Stroud R, Alford CS 1977 Virus-hos interactions in perinatally acquired cytomegalovirus infections of man: comparative studies on antigenic load and immune complex formation. In: Cooper MD, Dayton DH (eds) Development of Host Defenses. Raven Press, New York, pp 237-250

15. Eloi-Santos SM, Novato-Silva E, Maselli VM, Gazinelli G, Colley DG, CorreaOliveira R 1989 Idiotypic sensitization in utero of children born to mothers with schistosomiasis or Chagas' disease. J Clin Invest 84:1028-1031

16. Gill III TJ, Repetti CF, Metlay LA, Robin BS, Taylor FH, Thompson DS, Cortese AL 1983 Transplacental immunization of the human fetus to tetanus by immunization of the mother. J Clin Invest 72:987-996

17. Vanderbeeken Y, Sarfati M, Rose R, Delespesse G 1985 In utero immunization of the fetus to tetanus by maternal vaccination during pregnancy. Am J Reprod Immunol Microbiol 8:39-42

18. Lefvert AK, Osterman PO 1983 Newborn infants to myasthenic mothers: a clinical study and an investigation of acetylcholine receptor antibodies in 17 children. Neurology 33:133-138

19. El-Roeiy A, Gleicher N, Isenberg D, Kennedy RC, Schoenfeld Y 1987 A common anti-DNA idiotype and other autoantibodies in sera of offspring of mothers with systemic lupus erythematosus. Clin Exp Immunol 68:528-534

20. Collins AM, Roberton DM, Hosking CS, Flannery GR 1991 Oral immunisation with xenogeneic antibodies stimulates the production of systemic and mucosal anti-idiotypic antibodies. Immunol 73:388-393

21. Zhou EM, Dzuba-Fischer JMM, Rector ES, Sehon AH, Kisil FT 1991 A murine monoclonal anti-idiotypic antibody detects a common idiotope on human, mouse and rabbit antibodies to allergen Lol p IV. Scand J Immunol 34:307-316

22. Uytdehaag FGCM, Osterhaus ADME 1985 Induction of neutralizing antibody in mice against poliovirus type II with monoclonal anti-idiotypic antibody J Immunol 134:1225-1229 